\title{
Growth, body composition and hematology of juvenile pacu (Piaractus mesopotamicus) fed increasing levels of ractopamine
}

\author{
[Crescimento, composição corporal e hematologia de juvenis de pacu (Piaractus \\ mesopotamicus) alimentados com quantidades crescentes de ractopamina] \\ A.J.A. Bicudo ${ }^{1}$, R.Y. Sado ${ }^{2}$; J.E.P. Cyrino ${ }^{3}$ \\ ${ }^{1}$ Universidade Federal Rural de Pernambuco - Garanhuns, PE \\ ${ }^{2}$ Universidade Tecnológica Federal do Paraná - Dois Vizinhos, PR \\ ${ }^{3}$ Universidade de São Paulo - Escola Superior de Agricultura "Luiz de Queiroz" - Piracicaba, SP
}

\begin{abstract}
The effects of four levels of dietary ractopamine (RAC) on growth, body composition and hematology of pacu, Piaractus mesopotamicus juveniles $(103.6 \pm 3.3 \mathrm{~g})$ were studied. Fish were housed into 12 circular tanks of $1 \mathrm{~m}^{3}$ - 15 fish per tank - and fed for 60 days with practical diets supplemented with 0; 10; 20 or 40mg RAC per kg of diet, in a totally randomized design trial $(\mathrm{n}=3)$. Fish fed diets containing up to $40 \mathrm{mg} \mathrm{RAC} / \mathrm{kg}$ diet for 60 days did not have improved growth or body composition parameters. There were no significant differences in hematocrit, hemoglobin and mean corpuscular hemoglobin. Plasma glucose and triglycerides were significantly smaller in fish fed with RAC; however no significant differences between RAC levels were detected. The inclusion of up to $40 \mathrm{mg} \mathrm{RAC} / \mathrm{kg}$ of diet did not improve growth and body composition, but influenced some hematological and biochemical parameters of juvenile pacu.
\end{abstract}

Keywords: fish, feed additive, repartitioning agents, Piaractus mesopotamicus, nutrition, hematological parameters

\section{RESUMO}

Estudou-se o efeito de quatro quantidades de ractopamina dietética (RAC) sobre o crescimento, a composição

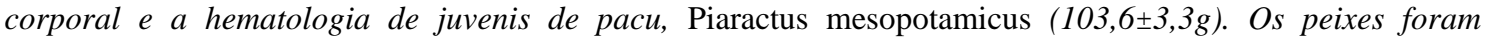
distribuídos em 12 tanques circulares de $1 \mathrm{~m}^{3}-15$ peixes por tanque - e alimentados por 60 dias com dietas práticas suplementadas com 0, 10, 20 ou 40mg RAC/kg de ração, em um delineamento inteiramente casualizado (n=3). Os peixes alimentados por 60 dias com dietas contendo até $40 \mathrm{mg}$ RAC/kg não apresentaram melhora no crescimento ou na composição corporal. Não houve diferença significativa nas concentrações de hematócrito, hemoglobina e hemoglobina corpuscular média. Glicose e triglicerídeos plasmáticos foram significativamente menores nos peixes alimentados com RAC, entretanto não houve diferença significativa entre os níveis de RAC. A inclusão de até 40mg RAC/kg de ração não melhorou o crescimento ou a composição corporal, mas influenciou alguns parâmetros hematológicos e bioquímicos de juvenis de pacu.

Palavras-chave: peixe, aditivo alimentar, agente repartidor, Piaractus mesopotamicus, nutrição, parâmetros hematológicos

\section{INTRODUCTION}

From a human nutrition standpoint, fish can be grouped according to muscle lipid contents: lean (<2\% lipid), low-fat (2-4\% lipid), medium-fat (4-8\% lipid) and high-fat (>8\% lipid) (Jobling, 2002). The pacu (Piaractus mesopotamicus), a neotropical, omnivorous South American Characin widely farmed in Brazil (Urbinati and Gonçalves, 2005), can be classified as a medium - (wild caught) to high-fat (farmed) species (Machado and Sgarbieri, 1991; Szenttamásy et al., 1993), an undesirable marketing trait.

Recebido em 6 de agosto de 2011

Aceito em 20 de julho de 2012

E-mail: alvaro.bicudo@uag.ufrpe.br 
Ractopamine hydrochloride (RAC) is a phenethanolamine, a repartitioning agent which can redirect nutrients from deposition in adipose tissue towards muscle accretion. In general, feeding phenethanolamines to animals increase weight gain, improve feed utilization efficiency, increase carcass leanness and dressing percentage (Mersmann, 1998). The efficacy of phenethanolamines has been demonstrated for lambs, broilers, turkeys, beef cattle and swine, but not all phenethanolamines are equally effective for all species (Moody et al., 2000).

In a previous study, Mustin and Lovell (1993) found that feeding channel catfish Ictalurus punctatus with diets containing either $20 \%$ or $36 \%$ crude protein (CP) supplemented with $20 \mathrm{mg} / \mathrm{kg}$ RAC led to a $24 \%$ and $18 \%$ decrease in visceral fat, respectively, and a $17 \%$ increase in weight gain; however, at highest dietary protein levels, fish presented reduced carcass protein deposition. The effects of repartitioning agents in performance and body composition of blue catfish Ictalurus furcatus (Webster et al., 1995), rainbow trout Oncorhynchus mykiss (Moccia et al., 1998; Vanderberg and Moccia, 1998; Vanderberg et al., 1998), and rohu Labeo rohita (Satpathy et al., 2001), were also determined, and results varied to a somewhat great extent.

The first Brazilian study about the use of RAC in animal feeding was performed by Bellaver et al. (1991) on swine in finishing growth phase, before the competent authority of Brazil, the Ministério da Agricultura, Pecuária e Abastecimento (MAPA), authorized the use of this product as a feed additive. Therefore, RAC is currently approved by MAPA strictly for commercial use in swine in finishing growth, and no beta-adrenergic are approved for use in fish feeds. At any rate, data on the effects of feeding phenethanolamines to neotropical fish are not available to date. This study was then set to determine effects of varying dietary RAC levels on growth performance, whole body composition and hematological parameters of juvenile pacu.

\section{MATERIAL AND METHODS}

A trial was set up in an indoor, recirculation system $(5 \mathrm{~L} / \mathrm{min}$ flow rate), under continuous aeration and emergency oxygenation systems, 12h L: $12 \mathrm{~h}$ D photoperiod, and controlled temperature $\left(27.9 \pm 1.3^{\circ} \mathrm{C}\right)$. The system's water quality parameters $-\mathrm{pH}(7.2 \pm 0.28)$, dissolved oxygen $(6.5 \pm 0.2 \mathrm{mg} / \mathrm{L})$, and ammonia $(\leq 0.5 \mathrm{mg} / \mathrm{L})$ remained within acceptable values for pacu (Urbinati and Gonçalves, 2005) throughout the trial. Pacu juveniles were obtained from commercial hatchery and acclimatized to the laboratory environment for one week, feeding to $3 \%$ of body weight on a commercial diet $(32 \%$ $\mathrm{CP})$.

A basal diet (27\% CP; Bicudo et al., 2009) was formulated and supplemented with RAC at 0,10 , 20 and $40 \mathrm{mg} / \mathrm{kg}$ of diet (Table 1). The ractopamine (Ractosuin ${ }^{\circledR}$, Ouro Fino Animal Health, Ribeirão Preto, SP, Brazil) was supplied as $2 \%$ ractopamine hydrochloride embedded in an inert carrier. After chemical analysis (Association of Official Analytical Chemists, 2000), feed ingredients were ground through a $1.0 \mathrm{~mm}$ sieve, homogenized and mixed in the calculated proportions, moistened with distilled water (25-30v:w) and pelleted $(2.0 \mathrm{~mm})$ in a mincer. Diets were then dried in a forced ventilation oven $\left(35^{\circ} \mathrm{C}\right.$ for $\left.24 \mathrm{~h}\right)$ and pellets were packed in black plastic bags, sealed and stored at $-4^{\circ} \mathrm{C}$ until use.

After acclimatization, fish were fasted $24 \mathrm{~h}$, weighed $(103.6 \pm 3.3 \mathrm{~g})$, randomly stocked into 1 $\mathrm{m}^{3}$ circular plastic tanks (15 fish per tank) in a totally randomized experimental design $(n=3)$ and fed with the experimental diets until apparent satiation twice a day (07:00 am and 04:00pm) for 60 days. Feed consumption was recorded weekly for each tank. The point of satiation was considered when fish started to refuse feed pellets.

Ten fish were sampled from the starting population, anesthetized with benzocaine solution (50mg/L; Pharmasys, Piracicaba, SP, Brazil) and blood samples were drawn from the caudal vein using 3-mL plastic syringes rinsed with EDTA $10 \%$ in $0.6 \%$ saline solution. A pooled sample of ten fish from the original population was also sacrificed by anesthetic overdoses $(500 \mathrm{mg} / \mathrm{L})$ to determine whole body composition. 
Table 1. Basal diet ingredients and composition (dry matter basis)

\begin{tabular}{|c|c|}
\hline Ingredient & Content \\
\hline & $\mathrm{g} / \mathrm{kg}$ \\
\hline Soybean meal & 350.0 \\
\hline Corn & 360.0 \\
\hline Corn gluten meal & 100.0 \\
\hline Rice broken & 100.0 \\
\hline Wheat bran & 50.0 \\
\hline Soybean oil & 32.7 \\
\hline Vitamin-mineral mix ${ }^{a}$ & 5.0 \\
\hline Dicalcium phosphate & 2.0 \\
\hline BHT $^{\mathrm{b}}$ & 0.3 \\
\hline \multirow[t]{2}{*}{ Nutrients } & Contents \\
\hline & $\mathrm{g} / \mathrm{kg}$ \\
\hline Moisture & 72.8 \\
\hline Crude protein & 279.7 \\
\hline Lipid & 66.9 \\
\hline Crude fiber & 22.4 \\
\hline Ash & 38.0 \\
\hline Gross energy $\left(\mathrm{kcal} \mathrm{kg}^{-1}\right)$ & 4,717 \\
\hline \multicolumn{2}{|c|}{$\begin{array}{l}{ }^{a} \text { Vitamin and mineral mix (Supre Mais }{ }^{\circledR} \text {; contents per } \\
\text { kg of diet): vit. A } 1.200 .000 \mathrm{UI} \text {; vit. } \mathrm{D}_{3} 200.000 \mathrm{UI} \text {; vit } \\
\text { E } 12.000 \mathrm{mg} \text {; vit. } \mathrm{K}_{3} 2.400 \mathrm{mg} \text {; vit. } \mathrm{B}_{1} 4.800 \mathrm{mg} \text {; vit. } \mathrm{B}_{2} \\
\text { 4.800mg; vit. } \mathrm{B}_{6} 4.000 \mathrm{mg} \text {; vit. } \mathrm{B}_{12} 4.800 \mathrm{mg} \text {; folic acid } \\
1.200 \mathrm{mg} \text {; calcium pantothenate } 12.000 \mathrm{mg} \text {; vit. C } \\
48.000 \mathrm{mg} \text {; biotin } 48 \mathrm{mg} \text {; choline } 65.000 \mathrm{mg} \text {; niacin } \\
24.000 \mathrm{mg} \text {; Fe } 10.000 \mathrm{mg} \text {; Cu } 600 \mathrm{mg} \text {; Mn } 4.000 \mathrm{mg} \text {; } \\
6.000 \mathrm{mg} \text {; } 20 \mathrm{mg} \text {; Co } 2 \mathrm{mg} \text {, Se } 20 \mathrm{mg} \\
\text { b butyl-hydroxy-toluene }\end{array}$} \\
\hline
\end{tabular}

At the end of the trial, four fish were randomly sampled from each replicate for blood sampling as previously described. Subsequently, all fish were weighted and five animals from each tank were killed by anesthetic overdose, minced, quick frozen and stored at $-20^{\circ} \mathrm{C}$ for subsequent chemical analysis and determination of whole body composition.

The following growth indexes were calculated: weight gain (WG) = final weight-initial weight); feed efficiency $(\mathrm{FE})=$ weight gain/dry feed intake); daily feed intake index (DFI) $=\{$ feed intake/[(final weight + initial weight $) /$ $2] /$ days $\times 100\})$; specific growth rate $(\mathrm{SGR})=$ [100 $\times(\ln$ final weight $-\ln$ initial weight $) /$ day $])$ and protein efficiency ratio $(\mathrm{PER})=$ weight gain $\div$ total protein intake).

All chemical composition analyses of diets and whole body were performed according to AOAC (Association of Official Analytical Chemists,
2000). Crude protein $(\mathrm{N} \times 6.25)$ was determined by the Kjeldahl method; moisture was determined by drying to a constant weight in an oven at $105^{\circ} \mathrm{C}$; lipid contents were determined by ether extraction after acid hydrolysis; ash was determined in a muffle furnace at $550^{\circ} \mathrm{C}$ for $24 \mathrm{~h}$; crude fiber was determined by acid/alkali digestion; and nitrogen free-extract was calculated by difference (100 - crude protein crude lipid - crude ash - crude fiber).

Hematocrit (HTC; \%) was determined using microhematocrit capillaries after centrifugation for 5 minutes at $10.000 \times \mathrm{g}$. Total plasma protein concentration (TPP; g/dL) was determined with a clinical refractometer. Red blood cell count (RBC; $\left.10^{6} \mu / \mathrm{L}\right)$ was determined in a hemocitometer (Neubauer chamber) using Natt and Herrick (1952) diluent (1:200). Hemoglobin (HB; g/dL) was determined by the cyanometahemoglobin method (Collier, 1944) using a standard kit (Bioclin ${ }^{\circledR}$, Belo Horizonte, MG, Brazil); samples were centrifuged prior to absorbance evaluation in a spectrophotometer to remove nuclear debris. The mean corpuscular volume (MCV; $f \mathrm{~L})$, mean corpuscular hemoglobin $(\mathrm{MCH} ; \mathrm{pg})$ and mean corpuscular hemoglobin concentration (MCHC; g/dL) were calculated according to Wintrobe (1934).

Plasma was separated from remaining samples by centrifugation at $5.000 \mathrm{rpm}$ for 5 minutes and stored at $-20^{\circ} \mathrm{C}$ until biochemical analysis. Samples were analyzed within seven days from collection; samples were thawed immediately prior to analysis. Plasma glucose (GLU; mg/dL) was determined with a colorimetric test based on the oxidase/peroxidase reaction (Laborlab, Guarulhos, SP, Brazil) and plasma triglycerides (TG; mg/dL) was determined using a standard, commercial kit (Laborclin, Pinhais, PR, Brazil).

Data were submitted to one-way analysis of variance. Differences between treatment means were tested for significance $(\mathrm{P}<0.05)$ by Duncan's multiple range test using Statistica software (version 7.0, Statsoft, Inc., Tulsa, OK).

\section{RESULTS AND DISCUSSION}

The survival rate during the trial was $100 \%$ and all the experimental diets were well accepted by 
fish. Feeding RAC did not affect $(\mathrm{P}>0.05)$ any of the measured productive performance (Table 2). Several factors including diet composition, dosage and duration of treatment, age, weight and genetics have been shown to influence the response to phenethanolamines. It is important to understand the interactions of these factors with phenethanolamines in fish, since the use of these compounds in the livestock industry was successfully implemented (Moody et al., 2000).

Table 2. Growth performance of pacu (Piaractus mesopotamicus) juveniles fed different levels of ractopamine

\begin{tabular}{cccccc}
\hline $\begin{array}{c}\text { Dietary } \\
\text { ractopamine }\end{array}$ & $\begin{array}{c}\text { Weight } \\
\text { gain }\end{array}$ & $\begin{array}{c}\text { Feed } \\
\text { Efficiency }\end{array}$ & $\begin{array}{c}\text { Specific growth } \\
\text { rate }\end{array}$ & $\begin{array}{c}\text { Daily Feed } \\
\text { Intake }\end{array}$ & $\begin{array}{c}\text { Protein } \\
\text { Efficiency Ratio }\end{array}$ \\
\hline mg kg $^{-1}$ & $\mathrm{~g}$ & & \% per day & \% biomass & \\
0 & 108.9 & 0.99 & 1.41 & 1.61 & 3.52 \\
10 & 110.2 & 0.93 & 1.38 & 1.65 & 3.33 \\
20 & 113.3 & 0.94 & 1.49 & 1.77 & 3.36 \\
40 & 109.8 & 0.92 & 1.43 & 1.73 & 3.27 \\
$\mathrm{P}$ & 0.98 & 0.57 & 0.76 & 0.22 & 0.58 \\
SEM & 3.72 & 0.02 & 0.03 & 0.03 & 0.07 \\
\hline
\end{tabular}

SEM: Standard error of mean.

Dietary RAC did not increase weight gain of juvenile pacu. This observation equals results generally reported for swine fed RAC (Stites et al., 1991; Yen et al., 1991). Maximizing responses to dietary phenethanolamines requires increasing dietary protein concentrations (Williams et al., 1994; Weldon and Armstrong, 2001). However, Webster et al. (1995) and Moccia et al. (1998) also did not register effects of phenethanolamines on weight gain of blue catfish and rainbow trout, respectively, fed increasing protein levels.

Mustin and Lovell (1995) fed channel catfish diets containing 24,30 or $36 \% \mathrm{CP}$ and 0 or $20 \mathrm{mg}$ $\mathrm{RAC}$ per $\mathrm{kg}$ of diet, and reported that fish fed RAC at the highest level of dietary protein presented weight gain about $29 \%$ higher. However, $36 \%$ of dietary protein is a much higher level than that found on commercial channel catfish feeds, which ranges on $28-32 \%$ protein (Webster et al., 1995). Satpathy et al. (2001) also found significant increase of weight gain of rohu fingerlings fed the phenethanolamine salbutamol when dietary protein was increased from $30 \%$ to $40 \%$.

No data on dietary protein requirement of pacu with initial weight higher than $103 \mathrm{~g}$ is available.
Therefore, the basal diet was formulated using protein requirement of pacu with initial weight of 15g (Bicudo et al., 2009). Because small fish usually have higher protein requirements per unit weight than do larger fish (Webster and Lim, 2002), the protein content of the basal diet exceeded requirements of size class pacu used in the present study. Consequently, dietary protein was probably not limited to ractopamine action in the present study.

In general, the oral administration of RAC decreases fat deposition and increases protein deposition. Webster et al. (1995) showed that the repartitioning agent L644,969 was effective in reducing body lipid and increasing muscle protein deposition of blue catfish fed $27 \%$ dietary protein. However, whole body composition of pacu fed different levels of ractopamine also did not differ significantly after 60 days of feeding (Table 3). However, Boscolo et al. (2009) registered visceral fat decrease in pacu fed with ractopamine $(0,2.5,5.0,7.5$ and $10 \mathrm{mg} / \mathrm{kg}$ of diet) until 30 days, but no difference in fat content was observed after 60 days of feeding. This suggests that the administration time for the pacu must be less than 60 days. 
Growth, body composition...

Table 3. Whole body composition ( $100 \mathrm{~g}^{-1}$ dry matter basis) of pacu (Piaractus mesopotamicus) juveniles fed different levels of ractopamine

\begin{tabular}{|c|c|c|c|c|}
\hline Dietary ractopamine & Dry matter & Lipid & Crude protein & Ash \\
\hline $\mathrm{mg} \mathrm{kg}^{-1}$ & & --1 & & \\
\hline Initial population & 22.5 & 15.8 & 63.1 & 15.3 \\
\hline 0 & 33.2 & 37.2 & 48.7 & 10.9 \\
\hline 10 & 33.6 & 38.4 & 47.7 & 10.3 \\
\hline 20 & 34.3 & 40.3 & 46.7 & 10.4 \\
\hline 40 & 33.8 & 39.7 & 45.7 & 11.2 \\
\hline $\mathrm{P}$ & 0.77 & 0.36 & 0.65 & 0.76 \\
\hline SEM & 0.32 & 0.63 & 0.82 & 0.31 \\
\hline
\end{tabular}

SEM: Standard error of mean.

In fish, results obtained to date suggest that size is not the major factor for the lack of response of phenethanolamines (Moccia et al., 1998), although best responses were obtained in studies with smaller fish of different species. For instance, year-1 channel catfish (Mustin and Lovell, 1995) presented better weight gain (29\% higher) than year-2 channel catfish (Mustin and Lovell, 1993) when fed the same protein $(36 \%)$ and RAC $(20 \mathrm{mg} / \mathrm{kg})$ levels. A similar trend was observed in rainbow trout juveniles; 196-g fish (Vanderberg and Moccia, 1998) presented better capacity to answer to dietary RAC than 385-g fish (Moccia et al., 1998). On the other hand, dietary phenethanolamines do not affect metabolism and performance of young, terrestrial animals (Mersmann et al., 1987; Anderson et al., 1988). Comparable results in growth performance were observed between the present study using pacu in initial growth phase (initial weight of 103g; 60-day trial) and the study of
Boscolo et al. (2009) with pacu in finishing growth phase (initial weight of $891 \mathrm{~g}$; 60-day trial). Despite the size difference, in both studies, no effect of RAC was evidenced on fish performance.

There were no significant differences in HTC, $\mathrm{HB}$ and $\mathrm{MCH}$ among fish fed diets with and without RAC (Table 4). The red blood cell count was higher $(\mathrm{P}<0.05)$ in fish fed $20 \mathrm{mg} \mathrm{RAC}$, but did not differ significantly from fish fed the control diet; consequently, MCV and MCHC were also not affected. GLU and TG were significantly smaller in groups fed RACsupplemented diets in comparison to those fed diets without RAC supplementation, but no differences $(\mathrm{P}>0.05)$ between RAC inclusion levels were detected. Total plasma protein was significantly smaller in fish fed diets with $40 \mathrm{mg}$ RAC than fish fed control diet.

Table 4. Haematological and blood biochemical parameters of pacu (Piaractus mesopotamicus) juveniles fed different levels of ractopamine

\begin{tabular}{|c|c|c|c|c|c|c|c|c|c|}
\hline $\begin{array}{c}\text { Dietary } \\
\text { ractopamine }\end{array}$ & Hematocrit & Hemoglobin & $\begin{array}{c}\text { Red } \\
\text { Blood } \\
\text { Cells }\end{array}$ & $\begin{array}{c}\text { Mean } \\
\text { Corpuscular } \\
\text { Volume }\end{array}$ & $\begin{array}{c}\text { Mean } \\
\text { Corpuscular } \\
\text { Hemoglobin }\end{array}$ & $\begin{array}{c}\text { Mean } \\
\text { Corpuscular } \\
\text { Hemoglobin } \\
\text { Concentration }\end{array}$ & $\begin{array}{c}\text { Total } \\
\text { Plasma } \\
\text { Protein }\end{array}$ & $\begin{array}{l}\text { Plasma } \\
\text { Glucose }\end{array}$ & $\begin{array}{c}\text { Plasma } \\
\text { Triglyceride }\end{array}$ \\
\hline $\mathrm{mg} \mathrm{kg}^{-1}$ & $\%$ & $\mathrm{~g} \mathrm{dL}^{-1}$ & $\begin{array}{l}10^{6} \\
\mu \mathrm{L}^{-1}\end{array}$ & $f \mathrm{~L}$ & $\mathrm{pg}$ & $\mathrm{g} \mathrm{dL}^{-1}$ & $\mathrm{~g} \mathrm{dL}^{-1}$ & $\mathrm{mg} \mathrm{dL}^{-1}$ & $\mathrm{mg} \mathrm{dL}^{-1}$ \\
\hline 0 & 32.1 & 10.26 & $\begin{array}{c}1.67 \mathrm{a} \\
\mathrm{b}\end{array}$ & $192.4 \mathrm{ab}$ & 61.2 & $31.7 \mathrm{ab}$ & $4.82 \mathrm{a}$ & $72.5 \mathrm{a}$ & 646.1a \\
\hline 10 & 32.5 & 9.86 & $\begin{array}{c}1.61 \mathrm{a} \\
\mathrm{b}\end{array}$ & $205.2 \mathrm{ab}$ & 62.2 & $30.3 b$ & 4.68ab & $66.4 \mathrm{~b}$ & $403.9 b$ \\
\hline 20 & 32.8 & 10.52 & $1.83 \mathrm{a}$ & $183.7 b$ & 59.2 & $32.3 \mathrm{a}$ & $4.86 \mathrm{a}$ & $66.1 b$ & $404.3 b$ \\
\hline 40 & 32.9 & 10.17 & $1.55 \mathrm{~b}$ & $212.9 \mathrm{a}$ & 65.9 & $31.0 \mathrm{ab}$ & $4.56 \mathrm{~b}$ & $65.3 b$ & $402.5 b$ \\
\hline $\mathrm{P}$ & 0.88 & 0.29 & 0.03 & 0.03 & 0.19 & $<0.01$ & $<0.01$ & 0.02 & $<0.01$ \\
\hline SEM & 0.30 & 0.10 & 0.03 & 3.63 & 1.18 & 0.21 & 0.03 & 0.96 & 27.59 \\
\hline
\end{tabular}

Means in the same column with different superscripts differ $(\mathrm{P}<0.05)$ by Duncan's test.

SEM: Standard error of mean. 
In general, the oral administration of phenethanolamines decreases fat deposition by activating hormone-sensitive lipase in adipose tissue, leading to increased lipolysis with consequent elevation in plasma triglycerides (Yen et al., 1989) and blood glucose by glycogenolysis and gluconeogenesis stimulation (Vijayan et al., 1994). However, reduced $(\mathrm{P}<0.05)$ plasma glucose and triglycerides in fish fed diets containing RAC was herein recorded.

Alterations in blood biochemistry mirror the use and metabolism of nutrients by animals. The differences $(\mathrm{P}<0.05)$ registered for $\mathrm{RBC}, \mathrm{MCV}$ and $\mathrm{MCHC}$ are not consistent and the values found represent the normal range for pacu (Ranzani-Paiva et al., 1998, 1999; Tavares-Dias et al., 1999). There is a close relationship between plasmatic protein and protein metabolism, nutritional status and tissue proteins (Coles, 1984). Although TPP was significantly affected by dietary RAC, no logical explanation was found for the recorded results. Measurement of absolute concentrations of plasma metabolites may not be a true indicator of tissue activity since they are dependent on many factors, which include dietary nutrient input, endogenous production (e.g. non-essential amino acids), release and uptake by one or several tissues simultaneously (Vanderberg et al., 1998).

In regard to warm-blooded animals, the effects of the phenethanolamines are not as pronounced in birds as in sheep; in pigs the effects are qualified as intermediate and in cattle the responses are similar to that seen in sheep (López et al., 2002). Regarding fish, phenethanolamines had a more pronounced effect on performance, protein increase and fat reduction of Siluriforms (Mustin and Lovell, 1993; Mustin and Lovell, 1995; Webster et al., 1995). Moccia et al. (1998) speculated that differences in responses to RAC observed between Siluriforms and Salmonids could be partly caused by differences in rearing water temperatures. However, the Cyprinid rohu reared in warm water $\left(26-30^{\circ} \mathrm{C}\right)$ showed growth performance, protein increment and fat reduction similar to rainbow trout. In addition, this study shows that RAC did not affect growth performance and body composition of pacu juveniles, a neotropical, warm water Characin. According Vandenberg and Moccia (1998) the species' specificity for absorption, distribution, metabolism and excretion can alter the responses to a particular beta-agonist in any given species. In view of the limited information on the use of phenethanolamines in fish, future research is needed to clarify the effects of supplementation of RAC in fish diets.

\section{CONCLUSIONS}

Feeding ractopamine up to $40 \mathrm{mg} / \mathrm{kg}$ diet for 60 days did not improve growth or body composition of juvenile pacu, but influenced hematological and blood biochemical responses.

\section{ACKNOWLEDGMENTS}

Authors are indebted to Ouro Fino Animal Health (Ribeirão Preto, SP, Brazil) for providing the tested feed supplement - Ractosuin ${ }^{\circledR}$. AJAB (05/51968-9) and RYS (05/51967-2) thank Fundação de Amparo à Pesquisa do Estado de São Paulo (FAPESP) for granting their Doctoral scholarship. JEPC is a CNPq scholar.

\section{REFERENCES}

ANDERSON, D.B.; VEENHUIZEN, E.L.; WAITT, W.P. et al. The effect of starting weight on growth performance and carcass composition of finishing pigs fed ractopamine. J. Anim. Sci., v.66 (Sup. 1), p.279-280, 1988.

ASSOCIATION of official analytical chemists (AOAC). Official Methods of Analysis of AOAC. 17th ed. Washington: AOAC, 2000.

BELLAVER, C.; FIALHO, E.T.; FÁVERO, J.A. et al. Níveis de ractopamina na dieta e efeitos sobre o desempenho e características de carcaça de suínos em terminação. Pesq. Agropec. Bras., v.26, p.1795-1802, 1991.

BICUDO, A.J.A.; SADO, R.Y.; CYRINO, J.E.P. Growth and haematology of pacu, Piaractus mesopotamicus, fed diets with varying protein to energy ratio. Aquac. Res., v.40, p.486-495, 2009.

BOSCOLO, W.R.; LORENZ, E.K.; KLEIN, S. et al. Ractopamina em rações para pacu (Piaractus mesopotamicus) cultivados em sistema de tanque-rede no reservatório de Itaipú. In: SIMPÓSIO INTERNACIONAL DE NUTRIÇÃO E SAÚDE DE PEIXES, 3., 2009, Botucatu, Anais... Botucatu: FMVZ-UNESP, 2009. 3p. CD-ROM. 
COLES, E.H. Função hepática. In: COLES, E.H. (Ed.). Patologia Clínica Veterinária. 3.ed. São Paulo: Manole, 1984. p.185-219.

COLLIER, H.B. The standardization of blood haemoglobin determinations. Can. Med. Assoc. J., v.50, p.550-552, 1944.

JOBLING, M. Nutrient partitioning and the influence of feed composition on body composition. In: HOULIHAN, D.; BOUJARD, T.; JOBLING, M. (Eds.). Food intake in fish. Oxford: Blackwell, 2002. p.354-375.

LÓPEZ, H.S.; OLVERA, L.G.; CAMBREROS, L.O. Clenbuterol y otros $\beta$-agonistas: ¿uma opción para la producción pecuaria o un riesgo para la salud pública? Vet. Mex., v.33, p.137159, 2002.

MACHADO, M.G.S.; SGARBIERI, V.C. Partial characterization and nutritive value of proteins from pacu (Colossoma mitrei, Berg 1895). J. Agr. Food Chem., v.39, p.1715-1718, 1991.

MERSMANN, H.J. Overview of the effects of beta-adrenergic receptor agonists on animal growth including mechanisms of action. J. Anim. Sci., v.76, p.160-172, 1998.

MERSMANN, H.J.; HU, C.Y.; POND, W.G. et al. Growth and adipose tissue metabolism in young pigs fed cimaterol with adequate or low dietary protein. J. Anim. Sci., v.64, p.1384-1394, 1987.

MOCCIA, R.D.; GURURE, R.M.; ATKINSON, J.L. et al. Effects of the repartitioning agent ractopamine on the growth and body composition of rainbow trout, Oncorhynchus mykiss (Walbaum), fed three levels of dietary protein. Aquac. Res., v.29, p.687-694, 1998.

MOODY, D.E.; HANCOCK, D.L.; ANDERSON, D.B. Phenethanolamine repartitioning agents. In: D'MELLO, J.P.F. (Ed.). Farm Animal Metabolism and Nutrition. New York: CAB International, 2000. p.65-96.

MUSTIN, W.G.; LOVELL, R.T. Feeding the repartitioning agent, ractopamine, to channel catfish (Ictalurus punctatus) increases weight gain and reduces fat deposition. Aquaculture, v.109, p.145-152, 1993.
MUSTIN, W.G.; LOVELL, R.T. Dietary protein concentrations and daily feed allowance influence response of channel catfish, Ictalurus punctatus (Rafinesque), to ractopamine. Aquac. Nutr., v.1, p.21-26, 1995.

NATT, M.P.; HERRICK, C.A. A new blood diluent for counting the erythrocytes and leucocytes of the chicken. Poult. Sci., v.31, p.735-738, 1952.

RANZANI-PAIVA, M.J.T.; SALLES, F.A.; EIRAS, J.C. et al. Análises hematológicas de curimbatá (Prochilodus scrofa), pacu (Piaractus mesopotamicus) e tambaqui (Colossoma macropomum) das estações de piscicultura do Instituto de Pesca, Estado de São Paulo. Bol. Inst. Pesca, v.25, p.77-83, 1998/1999.

SATPATHY, B.B.; MUKHERJEE, D.; RAY, A.K. Effects of dietary inclusion of the betaadrenergic agonist, salbutamol, on growth performance and whole body composition of rohu Labeo rohita (Hamilton) fingerlings fed diets containing two protein levels. Aquac. Res., v.32, p.739-747, 2001

STITES, C.R.; McKEITH, F.K.; SINGH, S.D. et al. The effect of ractopamine hydrochloride on the carcass cutting yelds of finishing swine. $J$. Anim. Sci., v.69, p.3094-3101, 1991.

SZENTTAMÁSSY, E.R.; BARBOSA, S.M.V.B.; OETTERER, M. et al. Tecnologia do pescado de água doce: aproveitamento do pacu (Piaractus mesopotamicus). Sci. Agric., v.50, p.303-310, 1993.

TAVARES-DIAS, M.; TENANI, R.A.; GIOLI, L.D. et al. Características hematológicas de teleósteos brasileiros. II. Parâmetros sanguíneos do Piaractus mesopotamicus Holmberg (Osteichthyes, Characidae) em policultivo intensive. Rev. Bras. Zool., v.16, p.423-431, 1999.

URBINATI, E.C.; GONÇALVES, F.D. Pacu (Piaractus mesopotamicus). In: BALDISSEROTO, B.; GOMES, L.C. (Eds.). Espécies nativas para piscicultura no Brasil. Santa Maria: UFSM, 2005. p.225-246.

VANDERBERG, G.W.; MOCCIA, R.D. Growth performance and carcass composition of rainbow trout, Oncorhynchus mykiss (Walbaum), fed the $\beta$-agonist ractopamine. Aquac. Res., v.29, p.469$479,1998$. 
VANDERBERG, G.W.; LEATHERLAND, J.F.; MOCCIA, R.D. The effects of the beta-agonist ractopamine on growth hormone and intermediary metabolite concentrations in rainbow trout, Oncorhynchus mykiss (Walbaum). Aquac. Res., v.29, p.79-87, 1998.

VIJAYAN, M.M.; PEREIRA, M.C.; MOON, T.W. Hormonal stimulation of hepatocyte metabolism in rainbow trout following an acute handling stress. Comp. Biochem. Phys. C, v.108, p.321-329, 1994.

WEBSTER, C.D.; LIM, C. Introduction to Fish Nutrition. In: WEBSTER, C.D.; LIM, C. (Eds.). Nutrient requirements and feeding of finfish for aquaculture. New York: CABI Publishing, 2002. p.388-395.

WEBSTER, C.D.; TIU, L.G.; TIDWELL, J.H. et al. Effects of feeding the repartitioning agent L644,969 on growth and body composition of the blue catfish, Ictalurus furcatus, fed diets containing two protein levels reared in cages. Aquaculture, v.134, p.247-256, 1995.
WELDON, W.C.; ARMSTRONG, T.A. Impact of nutrition on the ractopamine response. $J$. Anim. Sci., v.79 (Suppl. 1), p.238-239, 2001.

WILLIAMS, N.H.; CLINE, T.R.; SCHINCKEL, A.P. et al. The impact of ractopamine, energy intake, and dietary fat on finisher pig growth performance and carcass merit. J. Anim. Sci., v.72, p.3152-3162, 1994.

WINTROBE, M.M. Variations on the size and hemoglobin content of erythrocytes in the blood of various vertebrates. Folia Haematol., v.51, p.32-49, 1934.

YEN, J.T.; NIENABER, J.A.; KLINDT, J. et al. Effect of ractopamine on growth, carcass traits, and fasting heat production of U.S. contemporary crossbred and Chinese meishan pure and crossbred pigs. J. Anim. Sci., v.69, p.4810-4822, 1991.

YEN, T.T.; ANDERSON, D.B.; VEENHUIZEN, E.L. Phenethanolamines: reduction of fat and increase of muscle, from mice to pigs. In: LARDY, H.; STRATMAN, F. (Eds.). Hormones, Thermogenesis, and Obesity. New York: Elsevier Science, 1989. p.455-464. 